\title{
PERBEDAAN HASIL BELAJAR SISWA MENGGUNAKAN MODEL KOOPERATIF TIPE NUMBERED HEADS TOGETHER (NHT) DAN THINK PAIR SHARE (TPS) PADA MATERI SISTEM PENCERNAAN MANUSIA DI KELAS XI IPA SMA NEGERI 1 KUALUH SELATAN
}

\author{
Sri Endang Lestari ${ }^{1 *}$, Mariaty Sipayung ${ }^{2}$, Ery Heriyati ${ }^{3}$ \\ ${ }^{\mathbf{1 , 2}}$ Program Studi Pendidikan Biologi, FMIPA, Universitas Negeri Medan, Medan JI. Willem Iskandar Psr. V Medan \\ Estate, Medan, Indonesia, 20221 \\ ${ }^{3}$ SMA Negeri 1 Kualuh Selatan, Jl. Besar Sidua-dua, LABURA, Indonesia, 21457 \\ *E-mail : sriendanglestari@yahoo.com
}

\begin{abstract}
ABSTRAK
Penelitian ini bertujuan untuk mengetahui perbedaan hasil belajar siswa dengan menggunakan model pembelajaran Numbered Heads Together dan model pembelajaran Think Pair Share pada materi sistem pencernaan manusia di kelas XI IPA SMA Negeri 1 Kualuh Selatan T.P. 2016/2017. Jenis penelitian ini adalah penelitian eksperimen semu. Populasi penelitian ini terdiri dari 140 siswa dan sampel terdiri dari 48 siswa yang diambil dengan cara purposive sampling. Alat pengumpul data dalam penelitian ini berupa tes pilihan berganda sebanyak 30 soal sebagai soal pretes dan postes. Teknik analisis data yang digunakan dalam penelitian ini adalah uji hipotesis dengan menggunakan rumus uji-t. Perhitungan hipotesis diperoleh harga $t_{\text {hitung }}(5,5290)>t_{\text {tabel }}(1,6801)$ berarti $\mathrm{H}_{0}$ ditolak dan $\mathrm{H}_{\mathrm{a}}$ diterima. Dengan demikian terdapat perbedaan hasil belajar siswa yang diajarkan dengan menggunakan model Numbered Heads Together dan Think Pair Share pada materi sistem pencernaan manusia di kelas XI IPA SMA Negeri 1 Kualuh Selatan T.P. 2016/2017.
\end{abstract}

Kata kunci : model pembelajaran, Numbered Heads Together, Think Pair Share

\section{ABSTRACT}

This research aim to know difference of student's learning result taught by Numbered Heads Together and Think Pair Share on human dygestive system main in class XI IPA SMA Negeri 1 Kualuh Selatan in academic year 2016/2017. This research was an quasi experiment. The population of this research that consist of 140 students and the sample consisted of 48 students taken by purposive sampling method. The instrument in this research is made in multiple choice test which have 30 numbers using as pretest and postest. Technique analyse data which used in this research is test the hypothesis using t-test formula. Hypothesis calculation obtained by price of $t_{\text {hitung }}$ $(5,5290)>t_{\text {tabel }}(1,6801)$ means $H_{0}$ rejected and $H_{a}$ accepted. Thus there are differences in student learning outcomes taught by using Numbered Heads Together and Think Pair Share models on human digestive system material in class XI IPA SMA Negeri 1 Kualuh Selatan in academic year 2016/2017.

Keyword: study model, Numbered Heads Together, Think Pair Share

\section{PENDAHULUAN}

Pendidikan adalah salah satu faktor yang sangat penting dalam meningkatkan sumber daya manusia demi kemajuan suatu bangsa. Oleh karena itu, kemajuan suatu bangsa sangat ditentukan kualitas sumber daya manusia dan kualitas sumber daya manusia bergantung pada kualitas pendidikannya. Berbicara tentang mutu pendidikan tentu tidak terlepas dari keberhasilan siswa dalam belajar. Keberhasilan dalam proses belajar salah satunya dapat dilihat dari hasil belajar yang dicapai siswa.

Melihat hasil belajar siswa yang masih rendah maka pemerintah telah melakukan berbagai upaya untuk memperbaiki dan meningkatkan mutu pendidikan. Secara umum ada beberapa masalah atau faktor-faktor yang mempengaruhi terjadinya perbedaan prestasi belajar siswa sehingga menyebabkan hasil belajar siswa di sekolah menjadi rendah seperti yang dikemukakan Slameto (2003) yaitu faktor internal dan eksternal. Faktor internal yang datang dari dalam diri siswa itu sendiri seperti, kecerdasan, kesehatan, cara belajar, bakat, minat, dan motivasi. Sedangkan faktor eksternal yang berasal dari luar diri siswa seperti, fasilitas belajar, keadaan lingkungan keluarga, sekolah dan lingkungan sekitar, serta media pembelajaran yang diberikan oleh guru. 
Berbagai faktor tersebut masing-masing memiliki kontribusi terhadap pencapaian prestasi belajar siswa. prestasi belajar yang baik menjadi tolak ukur kualitas pendidikan yang dilaksanakan.

Idealnya prestasi belajar siswa di sekolah apabila siswa memperoleh prestasi belajar yang baik dengan pengembangan tiga aspek yang ditampilkan oleh siswa di sekolah dalam melakukan proses belajar untuk pencapaian prestasi belajar siswa yang optimal sesuai dengan aspek kognitif yang dimiliki oleh siswa. Namun pada kenyataannya dari data yang didapatkan di SMA Negeri 1 Kualuh Selatan masih banyak siswa yang mendapat nilai di bawah Kriteria Ketuntasan Minimal (KKM) yaitu sebanyak 60\% dari 124 siswa dengan nilai KKM di sekolah tersebut adalah 75 . Berdasarkan hasil observasi dan wawancara dengan guru biologi di SMA tersebut terdapat banyak masalah yang yang menyebabkan hasil belajar siswa masih rendah diantaranya rendahnya minat belajar siswa, kurangnya keaktifan siswa dalam proses belajar mengajar seperti siswa tidak memperhatikan guru, siswa enggan bertanya meskipun ada materi yang belum paham, ketika diberikan pertanyaan sangat sedikit siswa yang ingin menjawab pertanyaan guru, dan ketika dimintai pendapat siswa lebih banyak diam. Kemudian proses pembelajaran yang dilakukan masih cenderung berpusat pada guru saja artinya guru kurang bervariasi dalam penggunaan model-model pembelajaran kooperatif dalam proses belajar mengajar. Kemudian media pembelajaran yang digunakan guru juga kurang bervariasi yaitu hanya menggunakan buku teks sehingga membuat siswa merasa bosan.

Mengatasi permasalahan di atas diperlukan suatu model pembelajaran yang mampu mengubah pandangan negatif siswa terhadap pelajaran biologi sehingga pelajaran biologi menjadi pelajaran yang menyenangkan bagi siswa khususnya materi sistem pencernaan manusia. Pada materi ini diperlukan waktu yang cukup panjang untuk dibahas dalam proses pembelajaran serta siswa masih kesulitan dalam memahami konsep fisiologi manusia, terutama fungsi organ dalam tubuh manusia. Hal tersebut seirama dengan pendapat Sari (2010) dalam Suardin (2015) bahwa materi IPA mengenai fisiologi manusia merupakan salah satu materi yang tidak dapat divisualisasikan secara langsung karena konsep fisiologi manusia mempelajari fungsi organ dalam tubuh manusia yang saling berkaitan satu sama lain. Selain itu siswa juga menganggap materi sistem pencernaan makanan pada manusia merupakan salah satu materi dalam mata pelajaran biologi yang membutuhkan pemahaman dan hafalan. Pada materi ini siswa diharuskan untuk memahami serta mengingat berbagai organ pencernaan manusia, enzim-enzim yang terlibat dalam pencernaan beserta fungsinya, dan yang terpenting adalah jalannya proses pencernaan itu sendiri (Rachmawati 2012). Agar terhindar dari hafalan dan membantu siswa dalam memahami materi yang sulit maka sangatlah tepat jika diajarkan dengan menggunakan model pembelajaran kooperatif, sebab dengan model pembelajaran ini siswa di dalam kelompok dapat mengambil bagian kecil masing-masing dan mendiskusikan secara bersama bagian yang mereka pelajari. Ini juga merupakan suatu cara yang dapat mengefisiensi waktu dan tenaga guru dalam mengajar sehingga guru memiliki banyak waktu untuk mengulang semester sebelum para siswa melaksanakan ujian akhir semester ataupun ujian akhir sekolah.

Model pembelajaran kooperatif ada beberapa tipe diantaranya adalah Numbered Heads Together (NHT) dan Think Pair Share (TPS) yang memberikan kesempatan kepada siswa untuk bekerjasama dengan orang lain. Pendapat ini diperkuat oleh Pakpahan dan Riwayati (2016) dalam Numbered Heads Together (NHT) guru akan memberikan pertanyaan dan setiap kelompok akan berdiskusi dan saling membantu demi tanggungjawab kelompok kemudian akan dipertanggungjawabkan oleh siswa sesuai dengan nomor permintaan guru dari masing-masing kelompok sehingga siswa akan aktif dan setiap siswa akan mendapat giliran masingmasing untuk menjawab pertanyaan guru sedangkan melalui Think Pair Share (TPS) siswa akan terlatih berpikir dengan baik dan meningkatkan kemampuan siswa menyampaikan pendapat dan menghargai pendapat orang lain. Dalam TPS siswa akan bekerja secara berpasangan kemudian saling mengungkapkan gagasan dan saling membantu satu sama lain. Kedua model tersebut diharapkan dapat mengarahkan siswa untuk berpikir, bekerjasama dan terlatih dalam menyampaikan pendapat.

Selain itu dengan diterapkannya model NHT dan TPS dalam pembelajaran diharapkan dapat meningkatkan hasil belajar siswa. Pembelajaran kooperatif tipe NHT pernah diteliti oleh beberapa peneliti sebelumnya salah satunya oleh Novelensia (2014) menyatakan bahwa penerapan pembelajaran kooperatif tipe NHT dapat meningkatkan hasil belajar siswa yaitu sebesar $82,55 \%$ dan termasuk dalam kategori sangat aktif. Sedangkan Saenab dan Puspita (2012) mengungkapkan bahwa model pembelajaran 
tipe TPS dapat meningkatkan hasil belajar siswa dari $31,25 \%$ menjadi $71,88 \%$.

Tujuan penelitian ini adalah untuk mengetahui hasil belajar biologi siswa dengan menggunakan model pembelajaran Numbered Heads Together (NHT), untuk mengetahui hasil belajar biologi siswa dengan menggunakan model pembelajaran Think Pair Share (TPS), serta untuk mengetahui perbedaan hasil belajar biologi siswa dengan menggunakan model pembelajaran Numbered Heads Together (NHT) dan Think Pair Share (TPS) pada materi sistem pencernaan manusia di kelas XI IPA SMA Negeri 1 Kualuh Selatan T.P. 2016/2017.

\section{METODE PENELITIAN}

Penelitian ini dilaksanakan di kelas XI IPA SMA Negeri 1 Kualuh Selatan, Jalan besar Gunting Saga Desa Sidua-dua Kecamatan Kualuh Selatan Kabupaten Labuhanbatu Utara Kode Pos 21457 pada bulan Maret-Mei 2017. Populasi dalam penelitian ini adalah seluruh siswa kelas XI IPA SMA Negeri 1 Kualuh Selatan Tahun Pembelajaran 2016/2017 berjumlah 140 orang siswa. Sampel penelitian ini diambil secara purposive sampling. Sampel yang diambil dalam penelitian ini sebanyak 48 orang siswa. Jenis penelitian yang digunakan dalam penelitian ini adalah penelitian eksperimen semu (quasi experiment). Desain eksperimen semu yang digunakan dalam penelitian ini ialah pretest postest control group design. Adapun desain penelitian yang digunakan dapat dilihat pada Tabel 1.

Tabel 1. Desain Penelitian

\begin{tabular}{cccc}
\hline Sampel & Pretes & Perlakuan & Postes \\
\hline XI IPA $_{1}$ & $\mathrm{~T}_{1}$ & $\mathrm{X}_{1}$ & $\mathrm{~T}_{2}$ \\
$\mathrm{XIIPA}_{2}$ & $\mathrm{~T}_{1}$ & $\mathrm{X}_{2}$ & $\mathrm{~T}_{2}$ \\
\hline
\end{tabular}

Keterangan:

$\mathrm{T}_{1}$ : Tes Pertama (pretes)

$\mathrm{T}_{2}$ : Tes Akhir (postes)

$\mathrm{X}_{1}$ : Perlakuan pada kelas XI IPA 1 dengan menggunakan model pembelajaran Numbered Heads Together (NHT).

$\mathrm{X}_{2}$ : Perlakuan pada kelas XI IPA 2 dengan menggunakan model pembelajaran Think Pair Share (TPS).

Instrumen yang digunakan dalam penelitian ini adalah tes hasil belajar siswa berupa tes berbentuk pilihan berganda. Teknik alisis data yang digunakan yaitu uji normalitas digunakan uji Liliefors dan uji homogenitasnya menggunakan uji F. Untuk mengetahui peningkatan hasil belajar siswa dari nilai pretes ke postes dilakukan dengan uji N-Gain. Untuk mengetahui penerimaan atau penolakan hipotesis maka dilakukan dengan uji hipotesis yaitu menggunakan uji-t .

\section{HASIL PENELITIAN}

Data yang diperoleh dari penelitian ini adalah hasil belajar siswa yaitu nilai pretes yang diujikan sebelum dilakukan sebelum dilakukan proses pembelajaran pada kedua kelompok sampel dan postes yang diujikan setelah dilakukan proses pembelajaran menggunakan model kooperatif Numbered Heads Together (NHT) pada kelas eksperimen I (XI IPA 1) dan kooperatif Think Pair Share (TPS) pada kelas eksperimen II (XI IPA 2) pada materi pokok sistem pencernaan manusia di kelas XI IPA SMA Negeri 1 Kualuh Selatan T.P. 2016/2017. Pretes dilakukan untuk mengetahui kemampuan awal siswa dari masing-masing sampel sebelum dilakukan proses pembelajaran dan postes dilakukan untuk melihat hasil belajar siswa dari masing-masing sampel setelah dilakukan perlakuan.

Dari hasil pretes diketahui nilai rata-rata hasil belajar siswa pada kelas Numbered Heads Together (NHT) sebesar 47,10 dengan standar deviasi sebesar 11,86 sedangkan pada kelas Think Pair Share (TPS) diketahui nilai rata-rata hasil belajar pretes sebesar 44,91 dengan standar deviasi sebesar 8,63. Dari hasil tersebut dapat dilihat bahwa tidak terdapat perbedaan nilai pretes antara kelas NHT dengan kelas TPS artinya kemampuan dua kelas yaitu sama sebelum dilakukan perlakuan. Dari hasil postes diketahui nilai rata-rata hasil belajar siswa pada kelas Numbered Heads Together (NHT) sebesar 89,10 dengan standar deviasi sebesar 8,88 sedangkan pada kelas Think Pair 
JURNAL PELITA PENDIDIKAN VOL. 5 NO. 2

Lestari, SE., Sipayung, M., Heriyati, E.

Halaman : $009-012$

Share (TPS) diketahui nilai rata-rata hasil belajar sebesar 75,83 dengan standar deviasi sebesar 7,63.

Sebelum melakukan uji-t terlebih dahulu dilakukan uji normalitas dan uji homogenitas. Uji prasyarat ini dilakukan untuk memastikan bahwa pengujian hipotesis dapat dilakukan dengan statistik parametrik yaitu uji-t. Uji prasyarat meliputi uji normalitas dan uji homogenitas varians. Uji normalitas pada penelitian ini menggunakan uji Liliefors dengan taraf signifikan $\alpha=0,05$. Adapun kriteria pengujian normalitas ini adalah jika $L_{0}<L_{\text {tabel }}$ maka sampel berdistribusi normal dan jika $L_{0}>L_{\text {tabel }}$ maka sampel tidak berdistribusi normal. Berdasarkan perhitungan hasil pretes pada kelas NHT $L_{0}(0,1293)<L_{\text {tabel }}(0,190)$ sehingga data kemampuan awal siswa memiliki distribusi normal sedangkan hasil pretes pada kelas TPS $L_{0} \quad(0,1871)<L_{\text {tabel }}(0,190)$ sehingga data kemampuan awal siswa memiliki distribusi normal. Berdasarkan perhitungan hasil postes pada kelas NHT $L_{0}(0,1587)<L_{\text {tabel }}(0,190)$ sehingga data hasil belajar siswa pada kelas NHT berdistribusi normal sedangkan hasil pretes pada kelas TPS $L_{0}(0,1487)<L_{\text {tabel }}(0,190)$ sehingga data hasil belajar siswa pada kelas TPS berdistribusi normal. Uji prasyarat lainnya yaitu uji homogenitas yaitu untuk mengetahui apakah kedua kelas homogen atau tidak dengan syarat jika $F_{\text {hitung }}<$ $F_{\text {tabel }}$ maka kedua kelas dikatakan homogen. Hasil perhitungan uji homogenitas untuk data pretes diperoleh bahwa $F_{\text {hitung }}(1,2477)<F_{\text {tabel }}(2,01)$ yang berarti data pretes memiliki varians yang homogen sedangkan perhitungan uji homogenitas untuk data postes diperoleh bahwa $F_{\text {hitung }}(1,354)<F_{\text {tabel }}(2,01)$ yang berarti data postes memiliki varians yang homogen. Untuk mengetahui peningkatan hasil belajar siswa menggunakan uji N-Gain yaitu diperoleh hasil perhitungan nilai N-Gain pada kelas NHT yaitu 0,79 dengan persentase peningkatan hasil belajar sebesar $79 \%$ sedangkan pada kelas TPS didapatkan nilai $\mathrm{N}$-Gain sebesar 0,56 dengan persentase peningkatan hasil belajar sebesar $56 \%$. Karena data yang dianalisis telah berdistribusi normal dan homogen maka uji hipotesis menggunakan uji-t sudah dapat dilakukan. Hasil pengujian hipotesis diperoleh bahwa $t_{\text {hitung }}(5,529)>t_{\text {tabel }}(1,6801)$. Dengan melihat hasil tersebut dapat disimpulkan bahwa $\mathrm{H}_{0}$ ditolak dan $\mathrm{H}_{\mathrm{a}}$ diterima yang berarti ada perbedaan signifikan hasil belajar siswa menggunakan model pembelajaran kooperatif tipe Numbered Heads Together (NHT) dengan Think Pair Share (TPS) pada materi sistem pencernaan manusia di kelas XI IPA SMA Negeri 1 Kualuh Selatan T.P. 2016/2017.
pISSN : 2338 - 3003

elSSN : 2502 - 3217

\section{PEMBAHASAN}

Dari hasil analisa data diperoleh bahwa rata-rata nilai biologi siswa pada pokok bahasan sistem pencernaan manusia yang diajarkan dengan model pembelajaran Numbered Heads Together (NHT) dan model pembelajaran Think Pair Share (TPS) dapat meningkatkan hasil belajar siswa bila dibandingkan dengan nilai sebelum kedua kelas dilakukan penelitian (perlakuan). Hasil postes menunjukkan bahwa nilai rata-rata hasil belajar siswa dengan menggunakan model pembelajaran Numbered Heads Together (NHT) mengalami peningkatan dari rata-rata 47,10 menjadi 89,10 yaitu mengalami peningkatan sebesar $68 \%$ sedangkan hasil postes menunjukkan bahwa nilai ratarata hasil belajar siswa dengan menggunakan model pembelajaran Think Pair Share (TPS) mengalami peningkatan dari rata-rata 44,91 menjadi 75,83 yaitu mengalami peningkatan sebesar $56 \%$. Berdasarkan hasil tersebut dapat dilihat adanya peningkatan hasil belajar siswa pada kedua kelas dimana pada kelas dengan menggunakan model pembelajaran NHT sedikit lebih tinggi dibandingkan menggunakan model pembelajaran TPS. Dapat dilihat juga dari rata-rata hasil belajar siswa melalui uji-t dimana didapatkan hasil $t_{\text {hitung }}>t_{\text {tabel }}(5,529>1,6801)$ dimana $H_{0}$ ditolak dan $\mathrm{H}_{\mathrm{a}}$ diterima yang memenunjukkan bahwa ada perbedaan signifikan hasil belajar siswa menggunakan model pembelajaran kooperatif tipe Numbered Heads Together (NHT) dengan Think Pair Share (TPS) pada materi sistem pencernaan manusia di kelas XI IPA SMA Negeri 1 Kualuh Selatan T.P. 2016/2017.

Berdasarkan perbedaan peningkatan hasil belajar pada kedua kelas penelitian dapat disimpulkan bahwa penggunaan model pembelajaran kooperatif tipe Numbered Heads Together (NHT) lebih baik untuk digunakan dalam mengajarkan materi sistem pencernaan manusia dibandingkan dengan model kooperatif tipe Think Pair Share (TPS). Sesuai dengan kenyataan yang didapat oleh peneliti bahwa disaat siswa berdiskusi menerapkan model kooperatif tipe NHT dalam kelompok setiap anggota yang lebih paham terhadap materi pelajaran atau pertanyaan yang diberi oleh guru dapat membantu siswa yang kurang paham sehingga setiap anggota kelompok dapat memahami dan menguasai materi pelajaran. Setiap anggota kelompok memiliki peran dan bertanggungjawab atas belajarnya dan juga temanteman sekelompoknya. Anggota kelompok menjadi lebih serius dalam berdiskusi karena mereka takut nomornya akan dipanggil oleh guru dan merasa malu jika tidak dapat menjawab pertanyaan. Pada saat guru memanggil salah satu nomor untuk menjawab 
pertanyaan yang telah didiskusikan mereka dapat menjelaskannya dengan baik dan benar. Hal ini menunjukkan adanya keberhasilan dalam kelompok.

Berkaitan dengan hal tesebut, Vygotsky dalam Isjoni (2009) menyatakan bahwa tingkat perkembangan potensial dapat disalurkan melalui pembelajaran kooperatif salah satunya yaitu tipe NHT. Kualitas siswa dibangun di ruang kelas sedangkan aktivitas sosialnya dibangun dan dikembangkan dalam bentuk kerjasama antara siswa yang satu dengan siswa yang lainnya dibawah bimbingan orang dewasa dalam hal ini adalah peneliti sendiri. Sejalan dengan hal tersebut Gustaviana dan Yunansyah (2013) mengemukakan bahwa model pembelajaran NHT merupakan salah satu tipe pembelajaran yang berbasis student centre yang dapat memfasilitasi semua siswa untuk aktif dalam pembelajaran dan saling membagikan ide-ide satu sama lain. Pembelajaran dengan menggunakan tipe NHT ini dapat melatih siswa untuk saling berbagi informasi, mendengar dengan cermat serta berbicara sesuai pendapat mereka masing-masing, sehingga setiap siswa dapat lebih aktif dalam pembelajaran. Dengan penerapan pembelajaran NHT maka akan tercipta suasana koordinasi dimana setiap siswa akan saling berkomunikasi, saling mendengarkan, saling berbagi, saling memberi dan menerima dan keadaan tersebut akan memupuk jiwa, sikap, dan perilaku yang pada akhirnya mampu membawa dampak positif berupa peningkatan hasil belajar sebagai salah satu indikator keberhasilan yang dilakukan.

Selain itu dalam diskusi di dalam model NHT para siswa juga terlihat lebih bertangungjawab atas pertanyaan yang diberikan oleh guru serta setiap anggota kelompok semua terlibat dalam menyelesaikan pertanyaan yang diberikan guru sehingga didapatkan jawaban yang paling tepat dalam kelompok tersebut. Hal ini sesuai dengan pendapat Astrawan (2014) yang mengatakan bahwa model pembelajaran NHT memberi kesempatan kepada siswa untuk membagikan ide-ide dan dan mempertimbangkan jawaban yang paling tepat. Tipe NHT lebih menekankan pada struktur khusus yang dirancang untuk mempengaruhi pola interaksi siswa dan memiliki tujuan untuk meningkatkan penguasaan akademik. Tipe ini dapat melibatkan siswa dalam menelaah bahan yang tercakup dalam suatu pelajaran dan mengecek pemahaman mereka terhadap isi pelajaran tersebut. Cara ini menjamin keterlibatan total semua siswa, yang sangat baik untuk meningkatkan tanggungjawab individu dalam kelompok.
Berbeda halnya dengan kelompok siswa yang diajar dengan model pembelajaran kooperatif tipe Think Pair Share (TPS) yang cenderung kurang semangat dan aktif karena pada pembelajaran dengan model TPS siswa lebih sulit menyatukan pendapat kelompok mereka karena pada awalnya setiap siswa sudah memiliki persepsi jawaban masalah masingmasing atas pertanyaan yang diberikan oleh guru. Akhirnya ide-ide yang keluar hanya sedikit dan pendapat yang diterima hanya sedikit sehingga masalah yang diberikan guru tidak terpecahkan secara tuntas.

Dilihat dari nilai rata-rata hasil belajar siswa terlihat model pembelajaran Numbered Heads Together (NHT) sedikit lebih baik dibandingkan dengan model pembelajaran Think Pair Share (TPS). Hal ini juga sependapat dengan Pakpahan dan Riwayati (2016) dalam penelitiannya menyatakan bahwa model pembelajaran NHT lebih baik dibandingkan model pembelajaran TPS hal ini dikarenakan dalam proses pembelajaran menggunakan model NHT siswa lebih aktif dan lebih memiliki kesempatan untuk bertanya kepada siswa yang lain dalam kelompoknya. Selain itu siswa juga akan belajar dan memahami lebih banyak materi yang diajarkan karena setiap siswa harus mampu dan bersedia untuk menjawab setiap pertanyaan dari guru. Karena guru akan menyebutkan nomor satu persatu untuk menjawab pertanyaan yang diberikan oleh guru. Dengan adanya pembagian nomor kepala siswa dalam pembelajaran NHT akan belajar menguasai materi lebih banyak. Model NHT menginginkan satu siswa yang mewakili kelompok tanpa menginformasikan sebelumnya kepada kelompok tersebut siapa yang akan menjadi wakilnya. Hal ini mampu meningkatkan tanggungjawab dalam kelompok. Setiap anggota kelompok harus menguasai materi pelajaran, karena memiliki peluang yang sama untuk dipanggil oleh guru. Jadi berdasarkan uraian di atas dapat dikatakan bahwa model pembelajaran Numbered Heads Together (NHT) dan Think Pair Share (TPS) mampu meningkatkan hasil belajar biologi siswa dan terdapat perbedaan signifikan peningkatan hasil belajar siswa antara kelas yang diajarkan dengan model pembelajaran Numbered Heads Together (NHT) dan Think Pair Share (TPS) dan model pembelajaran Numbered Heads Together (NHT) lebih baik untuk digunakan dalam mengajarkan materi sistem pencernaan manusia dibandingkan dengan model pembelajaran Think Pair Share (TPS) .

\section{KESIMPULAN}


Dari hasil penelitian yang telah dilakukan dapat diambil kesimpulan bahwa hasil belajar siswa menggunakan model Numbered Heads Together (NHT) pada materi sistem pencernaan manusia di kelas XI IPA SMA Negeri 1 Kualuh Selatan T.P. 2016/2017 mengalami peningkatan sebesar 79\% (dari rata-rata 47,10 menjadi 89,10 ) dan termasuk dalam kategori peningkatan hasil belajar yang tinggi kemudian hasil belajar siswa menggunakan model pembelajaran Think Pair Share (TPS) pada materi sistem pencernaan manusia di kelas XI IPA SMA Negeri 1 Kualuh Selatan T.P. 2016/2017 mengalami peningkatan sebesar $56 \%$ (dari rata-rata 44,91 menjadi 75,83 ) dan termasuk dalam kategori sedang serta ada perbedaan signifikan hasil belajar siswa yang menggunakan model pembelajaran Numbered Heads Together (NHT) dan Think Pair Share (TPS) pada materi sistem pencernaan manusia di kelas XI IPA SMA Negeri 1 Kualuh Selatan T.P. 2016/2017.

\section{UCAPAN TERIMA KASIH}

Terima kasih terkhusus Ibu Siti Rahma Tanjung, S.Pd selaku Kepala Sekolah SMA Negeri 1 Kualuh Selatan dan siswa-siswi kelas XI IPA SMA Negeri 1 Kualuh Selatan yang telah banyak membantu selama penelitian berlangsung.

\section{DAFTAR PUSTAKA}

Astrawan, I.G.B., (2014), Penerapan Model Kooperatif Tipe NHT dalam Meningkatkan Hasil Belajar Siswa Pada Materi Pelajaran IPA di Kelas V SDN 3 Tonggolobibi, Jurnal Kreatif Tadulako Online, 3(4): 227-242.

Gustaviana, T.D., dan Yunansah, H., (2013), Pengaruh Pembelajaran Kooperatif Tipe NHT Terhadap Hasil Belajar Siswa Pada Konsep Energi dan Perubahannya, Jurnal Antologi, 1(2): 1-6.

Isjoni, (2009), Pembelajaran Kooperatif: Meningkatkan Kecerdasan Komunikasi Antar Peserta Didik, Pustaka Pelajar, Yogyakarta.

Novelensia, ETP., Bektiarso, S., Maryani, (2014), Penerapan Pembelajaran Kooperatif Tipe Numbered Heads Together (NHT) disertai Metode Eksperimen dalam Pembelajaran Fisika di SMA, Jurnal Pendidikan Fisika, 3(3): 242-247.

Pakpahan, M., dan Riwayati, (2016), Perbedaan Hasil Belajar Menggunakan Model Pembelajaran Numbered Heads Together (NHT) dengan Think Pair Share (TPS) pada Materi Ekosistem di Kelas VII, Jurnal Pelita Pendidikan, 4(2): 86-92.
Rachmawati, D.A., (2012), Pengembangan Media Pembelajaran Komik Biologi Pada Materi Sistem Pencernaan, Universitas Negeri Malang, Malang.

Saenab, S., dan Puspita, I., (2012), Peningkatan Aktivitas dan Hasil Belajar Biologi Melalui Penerapan Model Pembelajaran Kooperatif Tipe Think Pair Share (TPS) Pada Siswa Kelas XI IPA 2 SMA Negeri 1 Mangkutana, Jurnal Bionature, 13(2): 127-135.

Slameto, (2013), Belajar dan Faktor-Faktor Yang Mempengaruhi, Rineka Cipta, Jakarta.

Suardin, (2015), Penerapan Metode Discovery Learning Pada Materi Sistem Pencernaan Untuk Meningkatkan Hasil Belajar Siswa Kelas VIII SMP Negeri 2 Labuan, Jurnal Kreatif Tadulako Online, 4(3): 254-261. 